\title{
IMMUNOFLUORESCENT STUDIES OF CHRONIC SINUSITIS
}

\author{
SEIICHIRO YOSHII, M. D.
}

Department of Otolaryngology, Mie University School of Medicine, Tsu

(Director: Y. Miyoshi, M. D.)

Chronic sinusitis is one of the most prevalent nasal illnesses in Japan, but the pathogenesis of chronic sinusitis has not been fully understood yet. Recent advances in immunology have provide convincing evidence that secretory immunoglobulins may have an important role in mucosal defense mechanism.

Fifty six specimens of maxillay mucosae and 17 of nasal mucosae were obtained by surgery from the patients with chronic sinusitis and studied in order to obtain information about the local immune mechanism. Immunofluorescent microscopic studies were undertaken to determine the presence and distribution of different immunoglobulins ( $\operatorname{IgA}, \operatorname{IgM}, \operatorname{IgG}$ and $\operatorname{IgE}$ ) and secretory component (SC) in nasal and maxillary mucosae. Additionally, the relationship between the histopathological types of chronic sinusitis and local immunoglobulins were studied.

Following results were obtained.

1) There was no difference in the location or production of immunoglobulin bearing cells and extracellular immunoglobulins between the infiltrative and edematous mucosae in histopathological type. In fibrotic type, fluorescent activity could not be established.

2) IgA and $\operatorname{IgM}$ bearing cells were demonstrated in the surface lamina propria and around the grandular tissue of maxillary mucosa. In the nasal mucosa, $\operatorname{Ig} A$ and $\operatorname{Ig} M$ bearing cells were localized around the grandular tissue. A small number of $\operatorname{IgG}$ bearing cells weae noted in lamina propria in maxillary and nasal mucosae. No IgE was noted.

3) Extracellular IgA and $\operatorname{IgM}$ were mostly localized in intercellular space of the mucosal epithelial cells, subepithelial interstitium and around the glands. In maxillary and nasal grandular cells, IgA and SC were localized in the apical portion of glandular cells and intercellular space of the grandular epithelia. IgG was predominantly distributed in the interstitium of most specimens, especially in the surface lamina propria but not seen in the grandular cells.

4) As inflammation became severer in the maxillary mucosae, IgA and IgM bearing cells were increased considerably, and especially, extracellular $\operatorname{IgG}$ was seen more brilliantly.

5) Although SC was detected in $82 \%$ of nasal mucosa examined, it was detected in $30 \%$ of the examined maxillary mucosae. These results indicated that there is immunological dissociation between nasal and maxillary mucosae.

The results suggested that the increase of $\operatorname{IgA}$ and $\operatorname{IgM}$ bearing cells could be due to an acceleration of local immune response, and the bulk of $\lg G$ derived from serum. The production of SC and polymeric IgA were lost in some infected maxillary mucosae. In these SC defficiency and/or decreased secretory IgA production and combined with IgG local immune reactions may contribute to enhancement and perpetuation of inflammation in the naso-maxillary system. 


\title{
免疫蛍光抗体法による慢性副鼻腔炎の研究
}

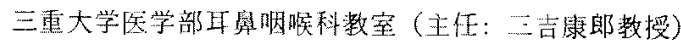 \\ 由其战一郎
}

\section{緒言}

気道には真接外界に接しながら，独特の望調機棈上共 代，粘液線毛系の機械的愉送機能，实覚その他知觉を介 した一種の神経反射，扣よび分论型 $\operatorname{Ig} \mathrm{A}(\mathrm{S}-\operatorname{Ig} \mathrm{A})$ の閶与

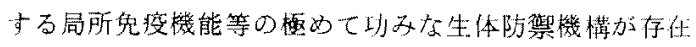
する，各してこれらは互いに密接に作用しあうことによ って，外界加与の異物侵入を防く一方，氛道夕日一二之 グを行いながら，人体の内部環境の恒常化に大きな役割

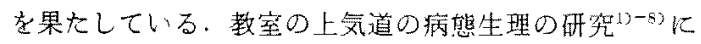

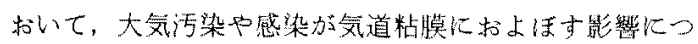
いて報告し，その中で粘液線毛系上局所免疼系が生体防

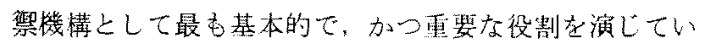
ることを埌告した，上产道の最初の胙户としての舅腔

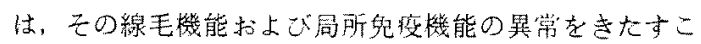
とにより，下気道，肺に重要な影㑭を和上ほするのとお

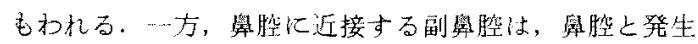

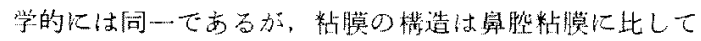
血管，神経，リンバ組粗などの発澾は势っている”。副

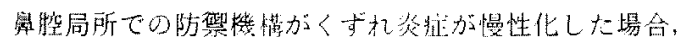

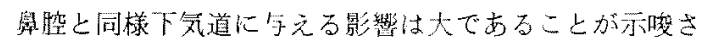

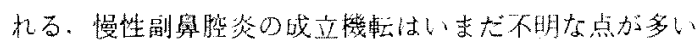
が，主たる原园として細菌感热とアレルギーが上げられ ている，最近ては1919年 Besredka河により始めて報告

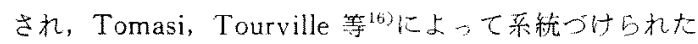

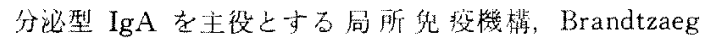

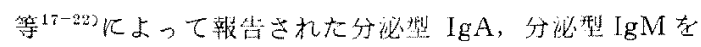
中心とする同所鬼疫㙨情が報告されている。また。 $\operatorname{Ig} G^{17233} ， \operatorname{IgE}^{21325 ;}$ が同所で産生されることが示され， こ礼らの允疾グロブリンは human respiratory tract 他

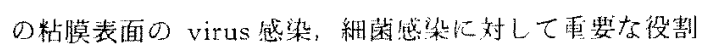

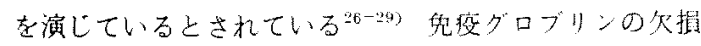

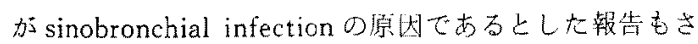

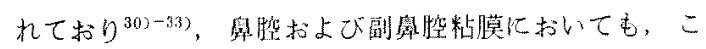
れらの兔疫グロブリンが感染防潔にあたると考光られ

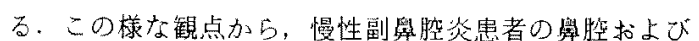

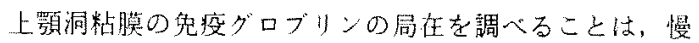

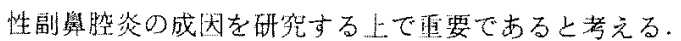

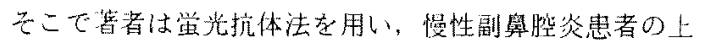
颚洞粘膜し下舆中介粘膜に打ける兒疫グロブリン IgA， $\operatorname{IgM}, \operatorname{IgG}, \operatorname{IgE}$, Secretory component (以下 $\mathrm{SC}$ ) の分

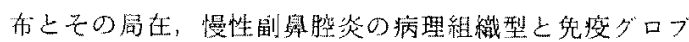

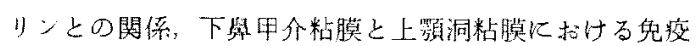

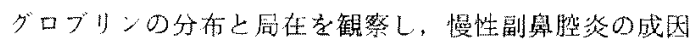

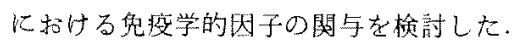

\section{実験村料および研究方法}

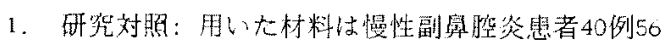
側上り手術時採取した上觀洞粘膜およて下舆甲介粘膜 17 例である。

2. 笛光抗体站

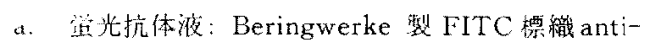
$\operatorname{IgA}$, anti-IgM, anti-IgG, anti-IgE（いすれれも H-chain specific). DAKO 製 anti-Secretory Piece of $\operatorname{IgA}$ 用 いた，使用した EITC 抗 IgA 血清は 7s-IgA と $115-$ IgA，抗 SC 皿清は Free SC $\measuredangle$ bound SC $\sigma$ 双方に证 降缐党形成した（第1图）。

b.人肝粉末上るる北異物質の吸收：抗体と組䅧成

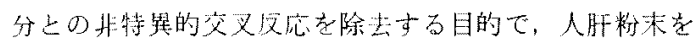

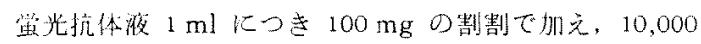
rpm で10分間邀观し，ての上清を积色に用いた。

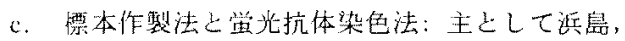

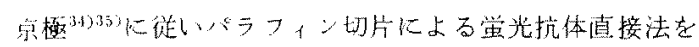

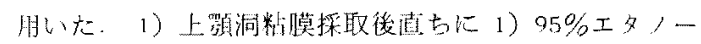
儿固定 $\left.\left(4^{\circ} \mathrm{C}, 24 \mathrm{hr}\right) .2\right) 100 \%$ 多 $/$ 一兀脱水 $\left({ }^{\circ} \mathrm{C}\right.$, $4 \mathrm{hr})$. 3) キシロール波に通す ( $4^{\circ} \mathrm{C}, 1-2 \mathrm{hr}$. 3changes). 4) அ゙ラフィン地埋 $\left(54-56^{\circ} \mathrm{C}, 2-4 \mathrm{hr}, 3\right.$ changes $)$ 5)

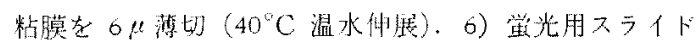

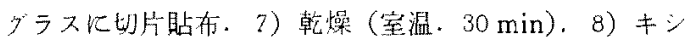


A

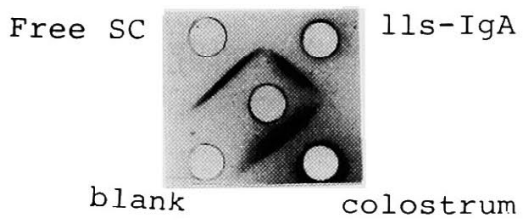

A center well FITC anti-SC
B

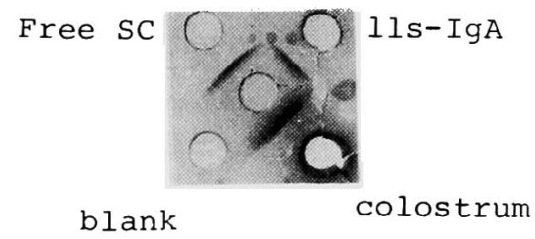

B center well anti-sc

Ouchterlony Analysis of FITC anti-IgA

C

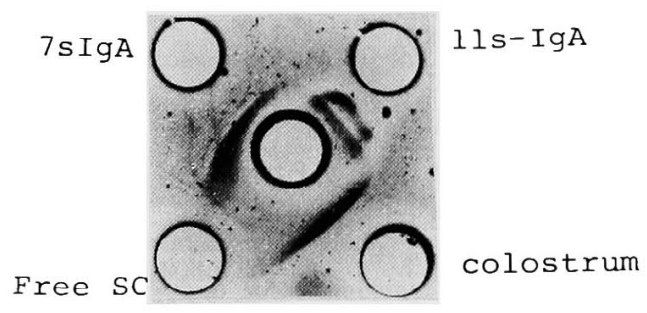

C center well FITC anti-IgA

図 1 Ouchterlony Analysis of FITC anti-SC

ロール液で脱パラ（9 min，3 changes）．9）100\%エタ ノールから順に 50\%エタノール (30-60 sec). 10) ph 7.2 phosphate buffered saline (PBS) で染浄 (15 min, 3 changes). 11) 切片に举光抗体液滴加（室温 moister chanber 内 $24 \mathrm{hr}$ ) , 12) PBS洗浄 (15 min, 3 changes) 13) Glycerin 封入. 14) 検鏡.

d. 対照染色：鸴光が特異鸴光であることを証明す るため, 一般阻止法および二段阻止法を用いて対照染色 を行い, 全例 HE学色を奏施した。また, 一部には Methylgreen-Pyronin 栥色, Toluidine-blue 染色を行っ た.

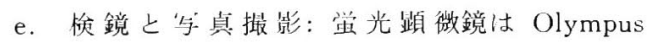

Model-FIM microscope, Olympus VANOX Model ARFL（西ドイツナスラム社製, 高圧水銀灯, $200 \mathrm{~W}$ ) を 使用し, フィルターは励起および吸収とも UV フィル ターを用いた．与真撮影は Kodak Ektachrome High speed (ASA 160) film と Kodak color II negative film を用い, 撮影条件は100倍で 30-120 秒, 200 倍で 45-150 秒で, 400 倍で 60-180 秒で撮影した。

憎本を㭥索するに際して, 上顎洞粘膜, 一鼻甲介粘膜

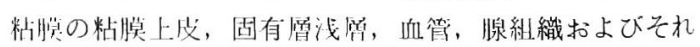
らの周辺部の細胞内と間質における単光の有無, 程度に ついて，それぞれ観浆した。兔疫グロブリン産生細胞の 数は, 1 临本につき最屯陽性細胞の多いとされる部位を 
3 視里 200 倍で检鏡し，その平均值より算定した。 また， 特翼䖝光の強さ㰞次の様な基染で判定し分類した。

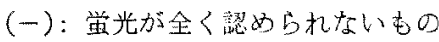

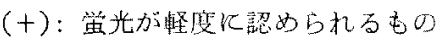

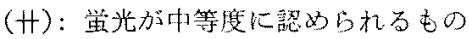

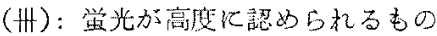

免疫グロブリン壁生細胞と局在性を示す特暴紧光は greenであり，自家蛍光上容易に区別し得た。

f. 病理組䅧型の分類：病理組織型の分類は, 同一 切片内で最も広い部分の組織变化をその病理型とし, 浸

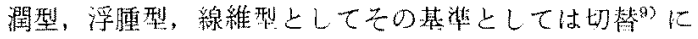
谁った。

\section{研 究成 續}

免疫グロブリン組織内分有

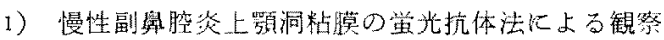

a) $\operatorname{IgA}$ 敛光陽性部位：第】表に示す如く，湜潤型 では. IgA 産生細胞は.71\%の症例の粘膜固有濖线層飞認 められ，58\%は9個以下の細胞がみられた疜例であっ

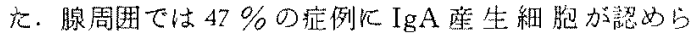
れ，やや固有厤浅愿火比して少ないが，細胞数は10倜以
上の症例方 $29 \%$ と多加大（写基1）．一方，粘膜上皮

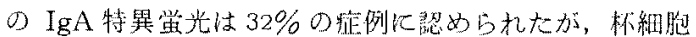

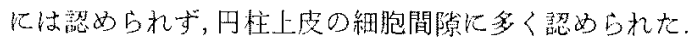

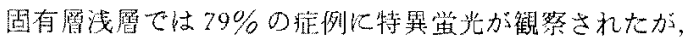

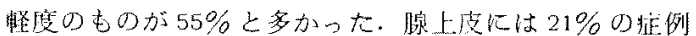
に証明され，IgA 特異営光山腺組胞の胞体内, 細胞間陪,

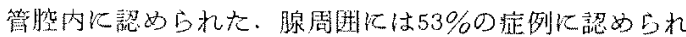

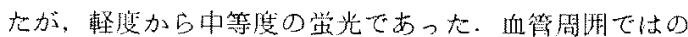

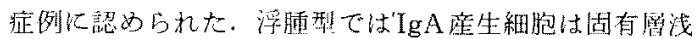

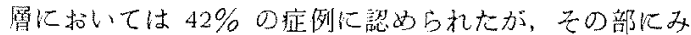
られた細胞数は9個以下のものが大部分であった，腺閣 四では 42\% の症例に珰められたが，細胞数は9㑬以下 の应例が多か力た，粘膜上皮 $\operatorname{IgA}$ 特簧学光は $67 \%$ と漫 潤型に比して，やや高率であった，固有層浅着では67\%

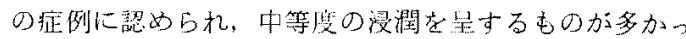

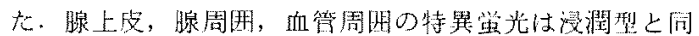
橡の所見が舅られた。

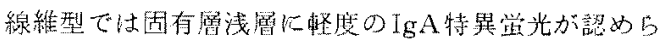
れるのみですった。

b) $\operatorname{IgM}$ 蛍光陽性部位：浸潤型では IgM 珄生紬胞 は固有層浅層，腺周四にそれそれれ $53 \% ， 32 \%$ の症例に

表 1 病理組織型と兒投グロブリン (56例)

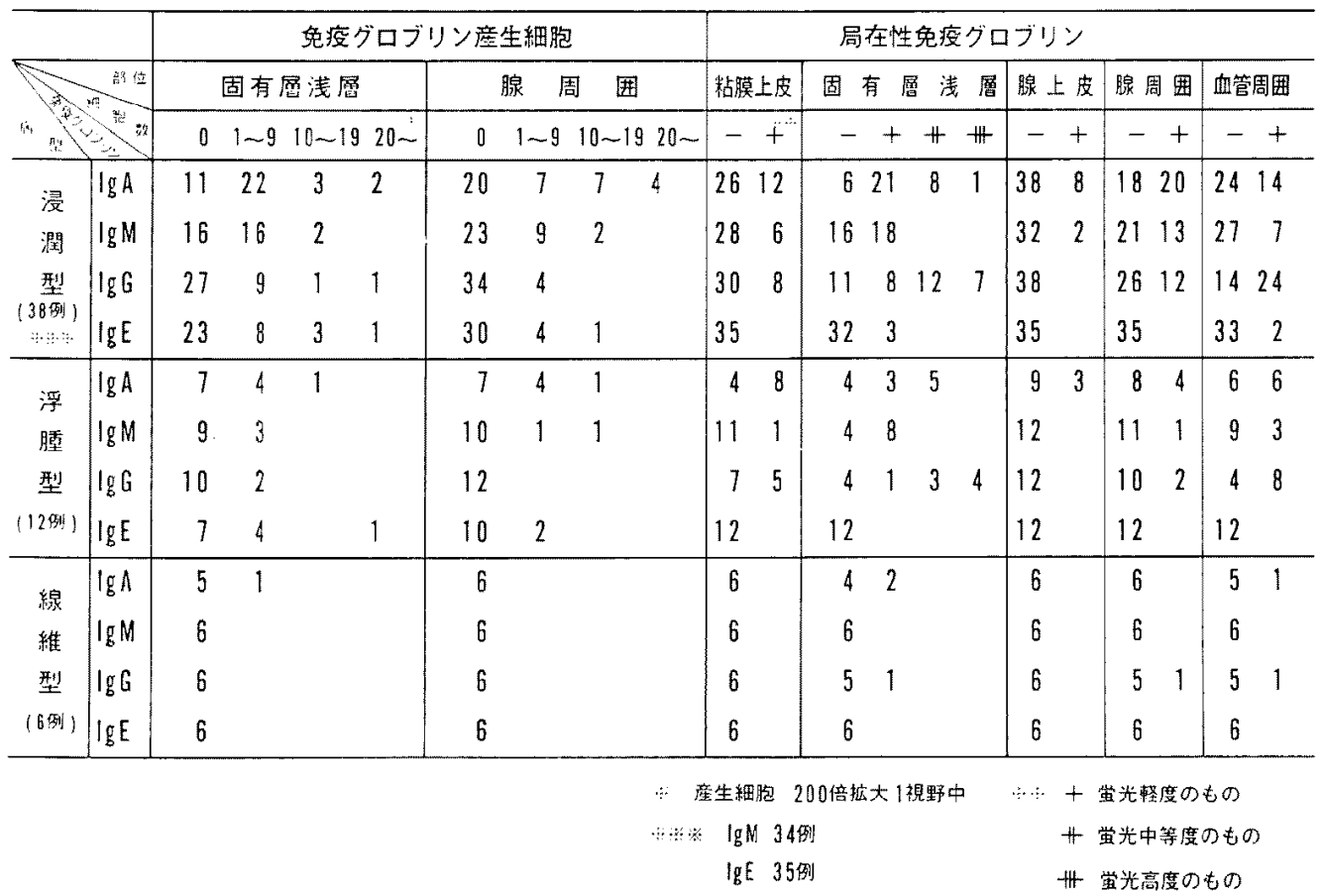


琶められたが，絸胞数が10倜以上のあのは，乙れぞれ2

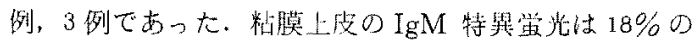

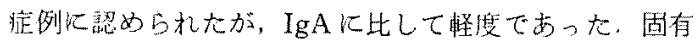
層浅層の IgM 特異営光は $50 \%$ 症列に㤎められたが，

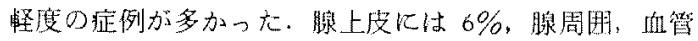
周井にはそれぞれ $32 \% ， 29 \%$ K軽度の特翼兴光が热好 bオた。

浮腫型では應生細胞, 特筫举光共に浸潤型とよく似た 所見が得られたが，全体としては，細胞数は少なく，特

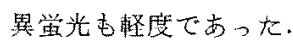

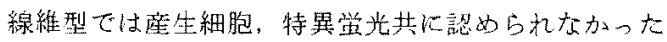
(第 1 表).

c) $\operatorname{IgG}$ 蛍光陽性部位：浸潤型，浮腆型共に $\operatorname{IgG}$ 産生細胞は IgA， IgM K比して固有層浅層，腺周目共 に漫潤が少なく，特に腺周間で情浸潤型の $11 \%$ の症例 に諗められたにす巳なかった，一方，浸潤型の固有㴔浅 層がは，約 $30 \%$ の症例諗めたが，乙の細胞数は9個

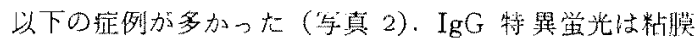
上皮では浮䑏型の $42 \%$ の症例に認められ，特にその䖪

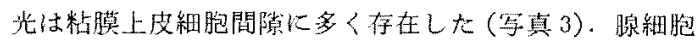

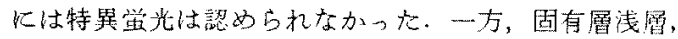

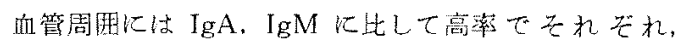

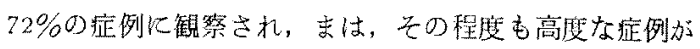
多加力大。

線維型では1例に特畏裳光が認められたにすぎなかっ 灰(第 1 表).

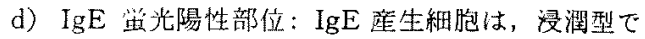

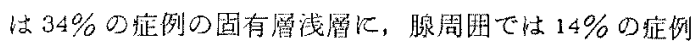
に認められたＩgE特異営光はほとんどの症例で証明さ 九なかった。浮腫型では $42 \%$ の症例の固有層浅層に，

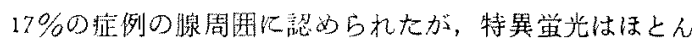
ど㒛めなか力た。

楾維型ては細胞监光，特翼监光は観祭できなかった (第1 表).

e) Secretory Component (SC) 举光陽性部位: 浸

表 2 病理組織型と Secretory Component (56例)

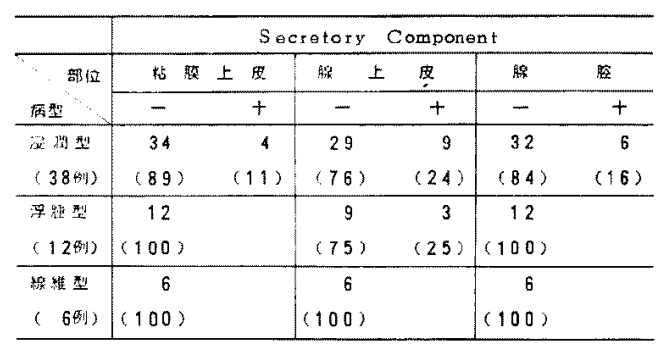

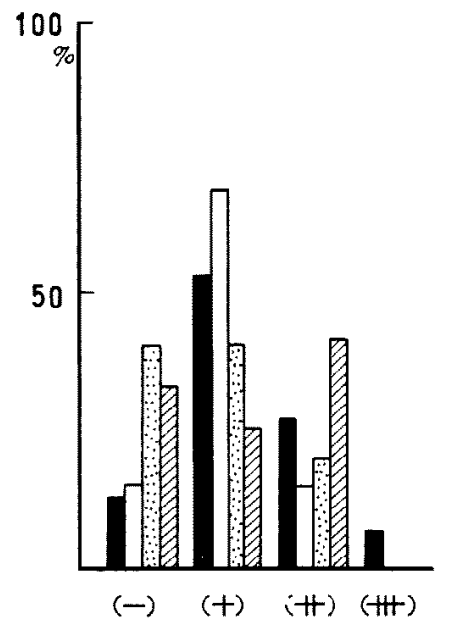

( Ig $A$ )

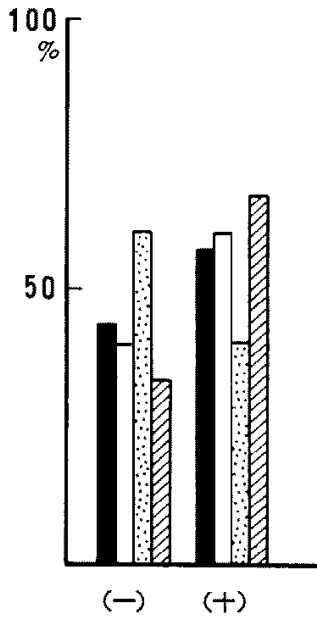

( Ig M)

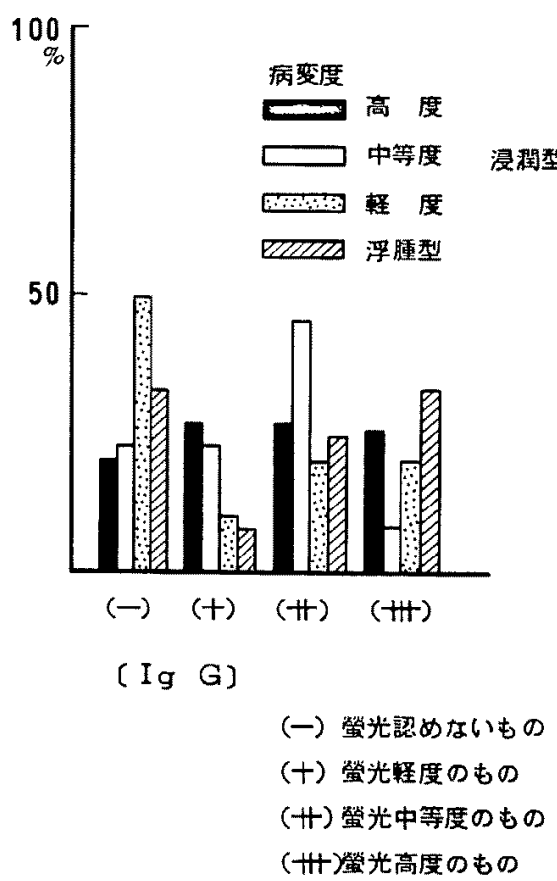

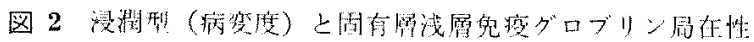




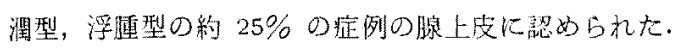

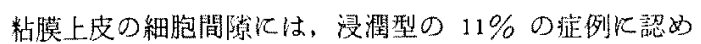
られたにすぎず，粘膜上皮，腺上皮のいづれにも SC の 瑟的られない症例は，浸潤型，浮連型 50 例のうち 35 例 約 70\%に認められなかった，腺上皮ては細胞閒源，脉 上皮細胞の尖端部飞近い部位飞特異举光がみられた。 SC は等液腺，粘液腺共飞認められたが，前者の方がよ

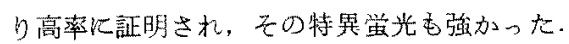

線維型では腺組織てのものがほとんどなく，SC を証 明し得なかった（第 2 表)。

f）浸潤型(病变度) と兔疫グロブリン座生細胞：上

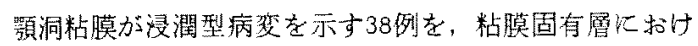
る細胞浸潤，血管の新生，腺組織の增生加它高度(14例)， 中等度 (14例)，軽度(10例)に分け，乙の病变度㕲よひ浮 腫型について IgA， IgM，IgG， IgE 座生細胞を比较し た (第 2 図).

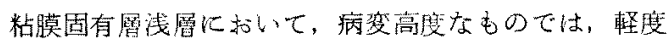
なものに比して IgM，IgG 㦃生細胞が多く漫潤する傾 向かみられた。腺周国では前者飞 $\operatorname{IgA}, \lg M, \operatorname{IgE}$ 産生 細胞が多く浸潤する傾向を示した。

浸溜型と浮腫型を比較すると，浸潤型病变度高度括よ び中等度の症例では粘膜固有畨浅層飞 IgA, IgM, IgG 座生細胞が多く認められる傾向がみられ，また，腺周囲 に怙いて前者に $\operatorname{IgA}, \operatorname{Ig} M$ 産生紐胞が多くみられる傾
间でホえた。

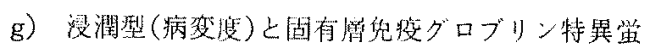

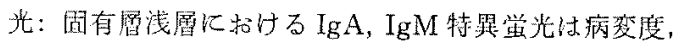
病型による差は認められない.IgG特罢兴光は病变が高 度になると，その特異举北も宫度となり，また，浮腫烈

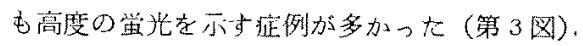

2）下奥甲介粘膜の举光抗体法による観察

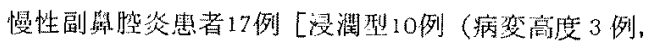
中等度 4 例，柽度 3 例), 浖腫型 5 例，線維型 2 例]

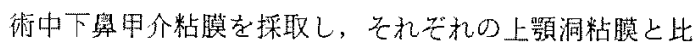

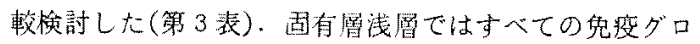
プリン浸潤が少なかった。一方，腺周囲で第 4 四に示 与如く IgA 産生細胞が多く瑟められ，また，IgA 産生

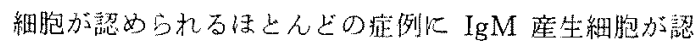
め市大。

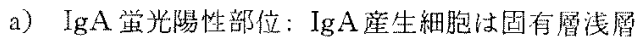
では2例に認められたにすきない，一方，䠌周国では $71 \%$ 症例儿琶められ，千の細胞数屯10個以上の症例拉

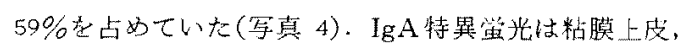

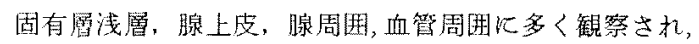
粘膜上皮では上皮細胞閔隚氏諗められた，腺上皮細胞で は，細胞間隙，管腔に近い部位に强く繻光が認められた (写真 4,5 ).

b) IgM 蛍光陽性部位：IgM 産生細胞は固有層浅層

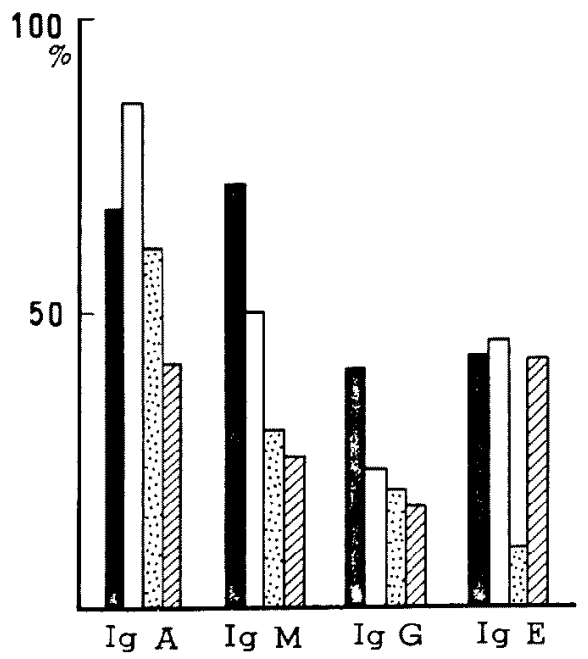

(粘膜固有曆戥層)

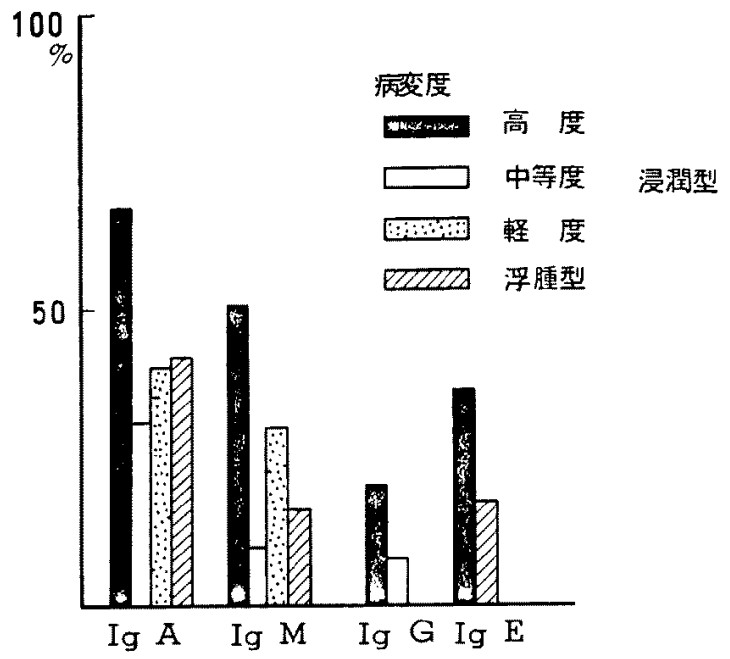

（腺 周 )

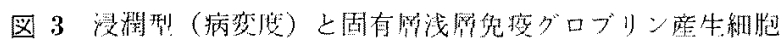


表 3

\begin{tabular}{|c|c|c|c|c|c|c|c|c|c|c|c|c|c|c|c|c|c|c|c|}
\hline \multirow{3}{*}{\multicolumn{2}{|c|}{ 部位 }} & \multicolumn{8}{|c|}{ 免疫グロブリソ笙生細胞 } & \multicolumn{10}{|c|}{ 局在性免疫グロブリン } \\
\hline & & \multicolumn{4}{|c|}{ 直有層浅層 } & \multicolumn{4}{|c|}{ ivis 周 囲 } & \multicolumn{2}{|c|}{ 新膜上皮 } & \multicolumn{4}{|c|}{ 固落層浅層 } & \multirow{2}{*}{\multicolumn{2}{|c|}{\begin{tabular}{|l} 
榢上皮 \\
-++ \\
\end{tabular}}} & 腺周国 & 血管周团 \\
\hline & & 0 & $1 \sim 9$ & $0 \sim 19$ & $20 \simeq$ & 0 & $1-9$ & $10 \sim 19$ & $20-$ & & + & & + & & & & & & -+ \\
\hline 上 & $\lg A$ & 10 & 5 & 1 & 1 & 12 & 2 & 2 & 1 & & 8 & & 8 & 6 & & 143 & & & 215 \\
\hline $\begin{array}{l}\text { 旗 } \\
\text { 洞 }\end{array}$ & $\operatorname{Ig} M$ & 11 & 5 & 1 & & 13 & 4 & & & 12 & & & 11 & & & 16 & & 125 & 98 \\
\hline 粘 & $\operatorname{Ig} G$ & 15 & 2 & & & 16 & 1 & & & 8 & 9 & 2 & 5 & G & 4 & 17 & & 116 & 215 \\
\hline 膜 & $\operatorname{IgE}$ & 14 & 2 & 1 & & 15 & 2 & & & 17 & & 15 & 2 & & & 17 & & 17 & $\begin{array}{ll}16 & 1\end{array}$ \\
\hline \multirow{4}{*}{ 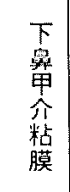 } & $\lg A$ & 15 & 2 & & & 4 & 3 & 8 & 2 & & 11 & & 7 & 6 & 1 & 41 & & 413 & 314 \\
\hline & $\lg M$ & 14 & 3 & & & ò & 11 & & & 10 & & & 13 & & & 13 & & 512 & $\begin{array}{lll}6 & 11\end{array}$ \\
\hline & $\lg G$ & 13 & 4 & & & 13 & 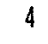 & & & 5 & 12 & 2 & 2 & 4 & 9 & 17 & & 512 & 314 \\
\hline & $\lg E$ & 16 & 1 & & & 15 & 2 & & & 17 & & 15 & 2 & & & 16 & & 17 & 17 \\
\hline
\end{tabular}

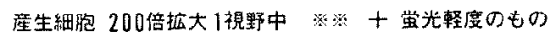

( ) : \%

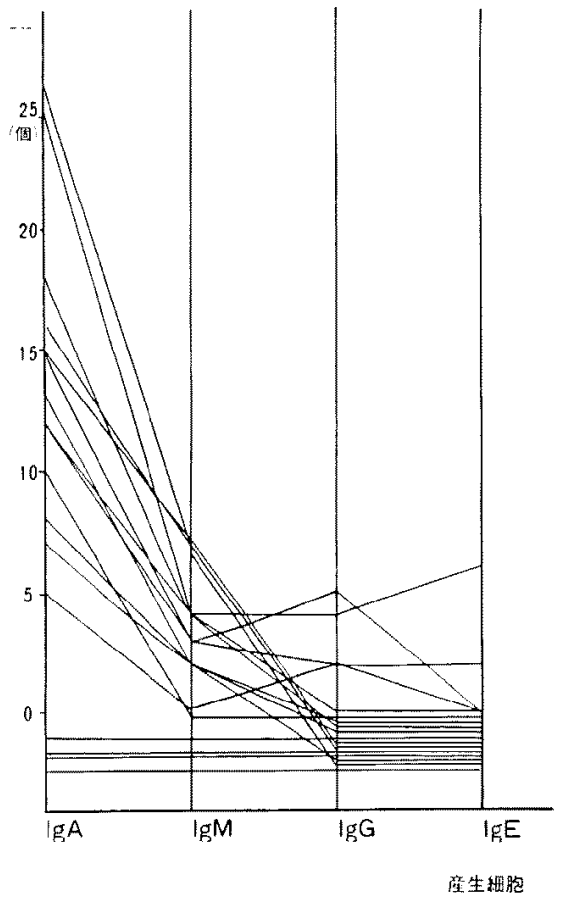

200倍痁大 1 視野中

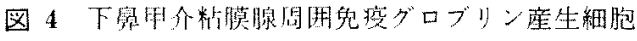

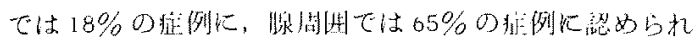

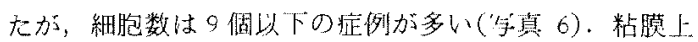

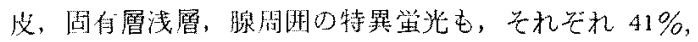

\#蛍光中等度のもの

井 蛍光高度のもの

表 4

\begin{tabular}{|c|c|c|c|c|c|c|}
\hline & \multicolumn{3}{|c|}{ Secretory } & \multicolumn{2}{|c|}{ Component } & \multirow[b]{2}{*}{ 胵 } \\
\hline & 粘 & 上皮 & 腺 & 上农 & 醁 & \\
\hline & - & + & - & + & - & + \\
\hline \multirow{2}{*}{ 上落洞粘滕 } & 16 & 1 & 11 & 6 & 14 & 3 \\
\hline & $(94)$ & (6) & (65) & (35) & $(82)$ & $(18)$ \\
\hline \multirow{2}{*}{ 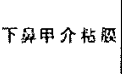 } & 11 & 6 & 3 & 14 & 8 & 9 \\
\hline & (65) & (35) & (18) & $(82)$ & $(47)$ & $(53)$ \\
\hline
\end{tabular}

$77 \% ７ 1 \%$ 症例の認められた（写真 7).

c) $\operatorname{IgG}$ 览光陽性部位：IgG 应生細胞は固有層浅 層，腺周国の各々4例に認められたが，その部にみられ た細胞数牥すべて9個以下の注例であった，粘膜上皮，

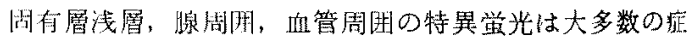

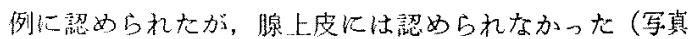
8).

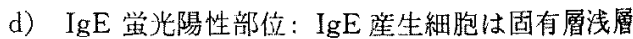

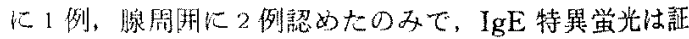
旧了されなかった。

e) SC 蛍光陽性部位：粘膜上皮，腺上皮腺腔内の

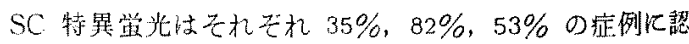

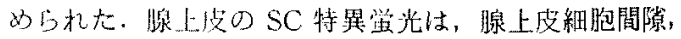

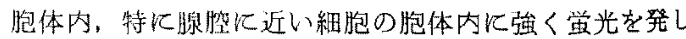
ているのが観祭された（第 4装）（写真 9，10）. 


\section{由井論文付网 (1)}

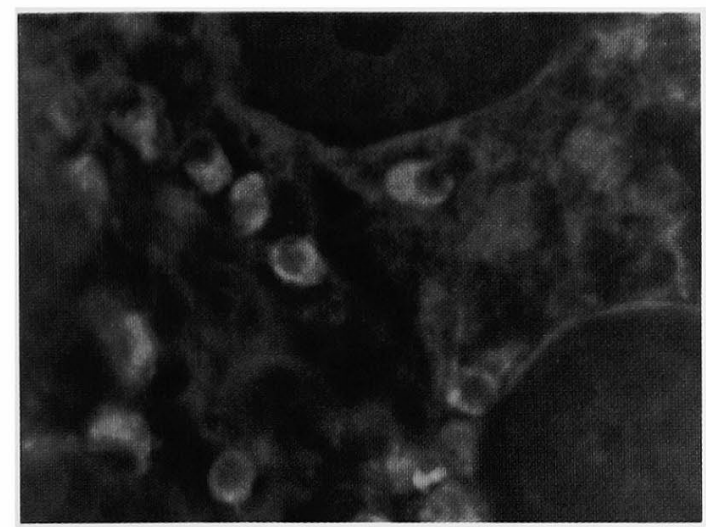

写真 1

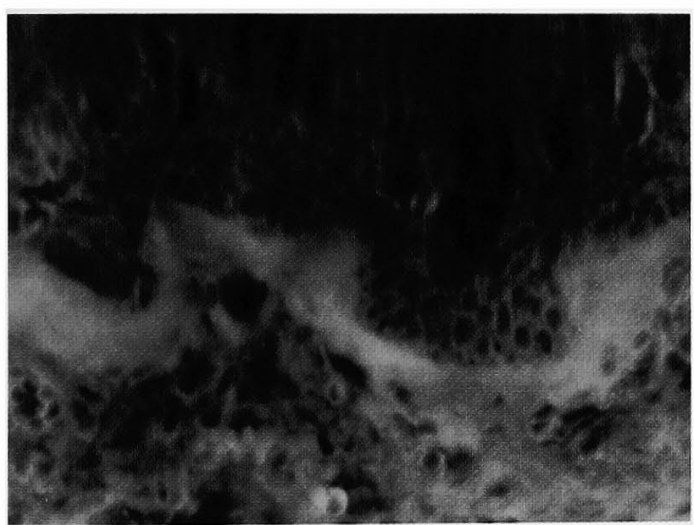

写真 3

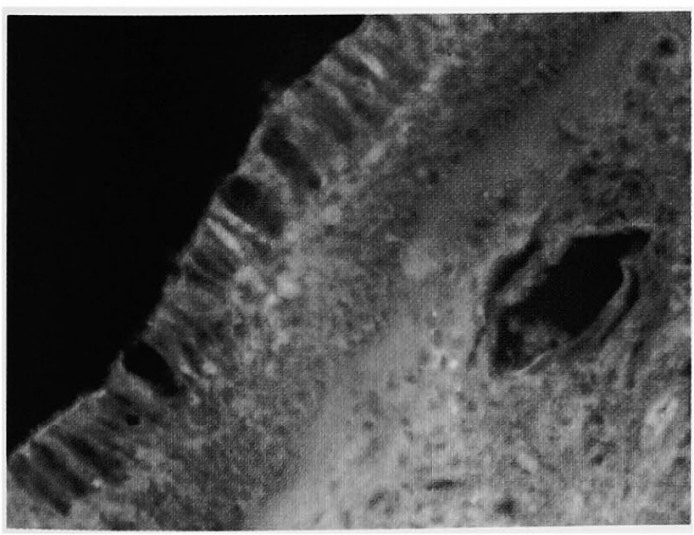

写真 5

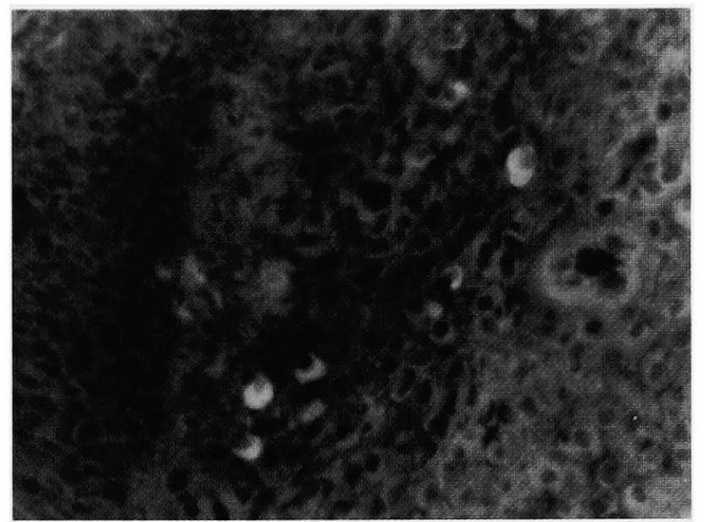

写真 2

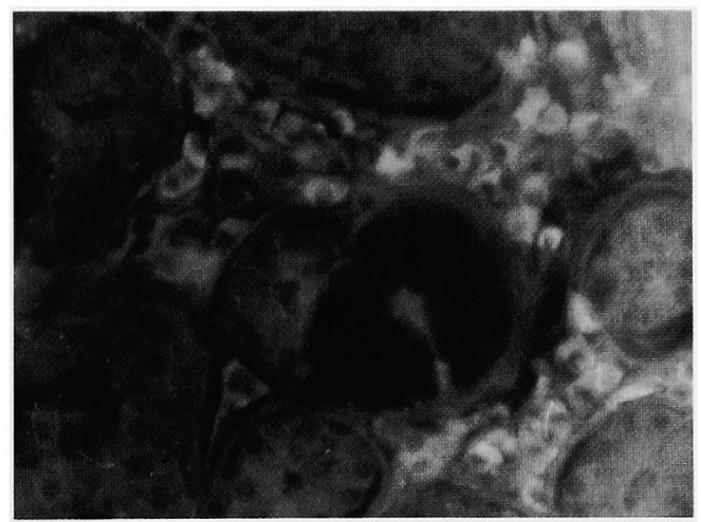

写真 4

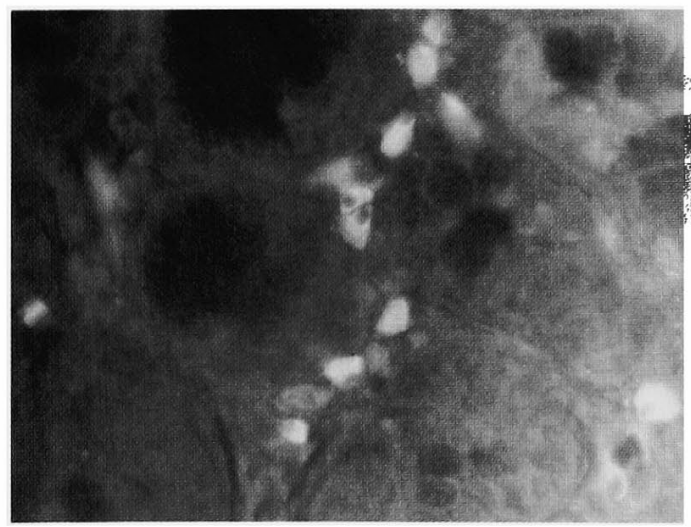

写真 6 


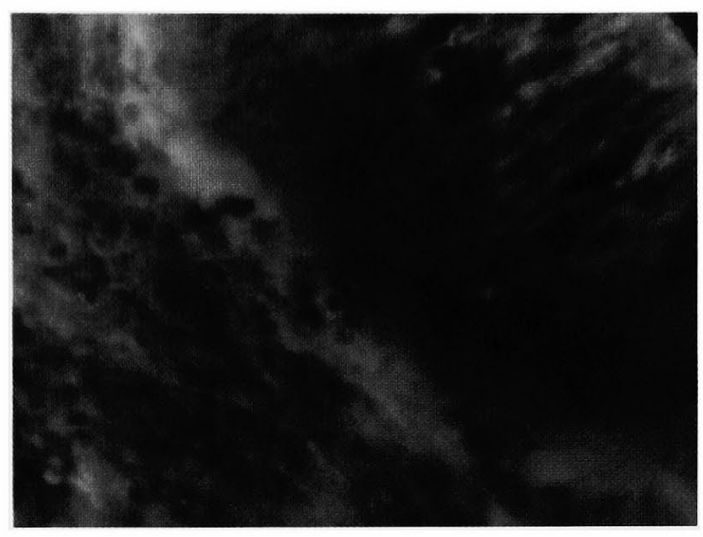

写真 7

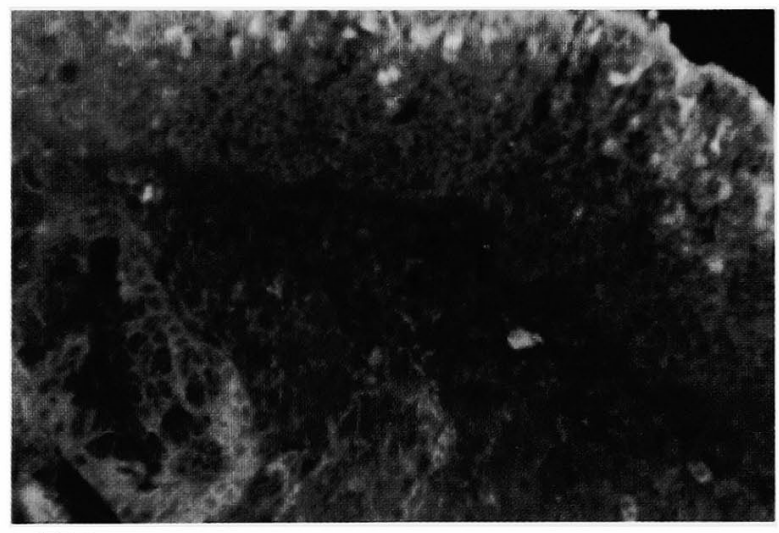

写真 9

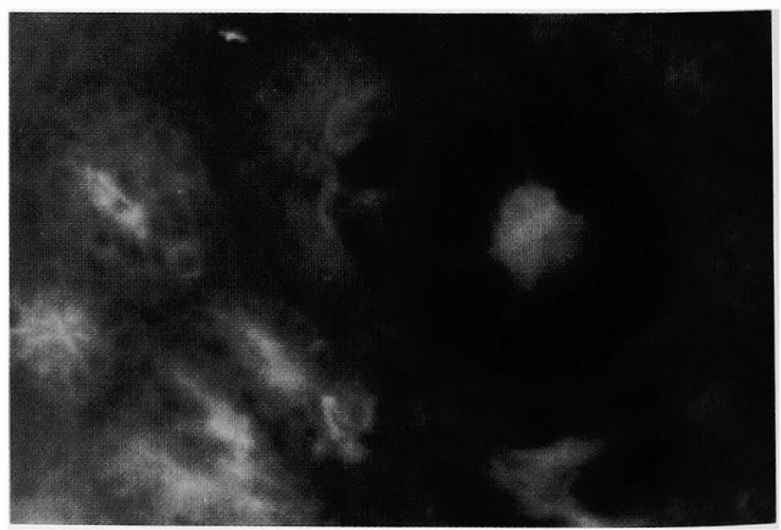

写真 10

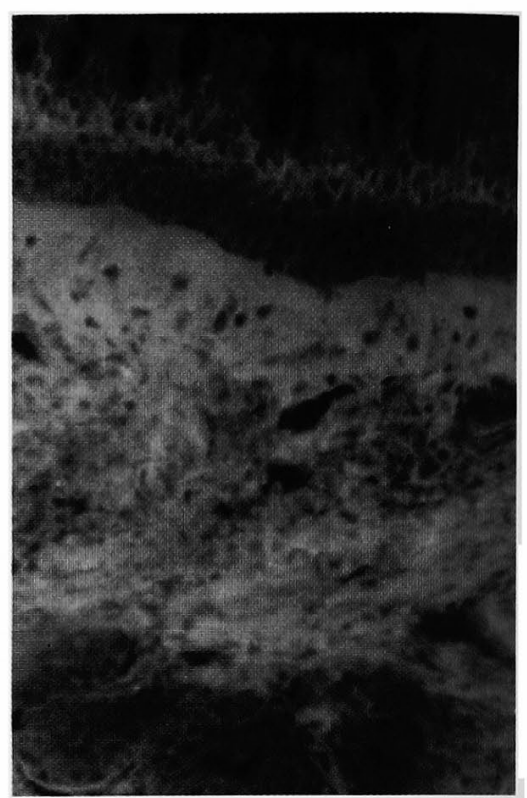

写真 8 


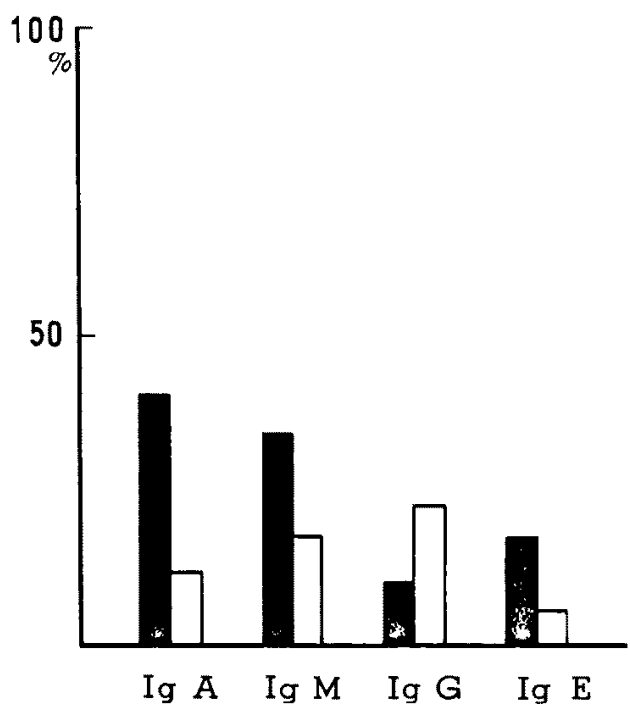

（固有層浅層）
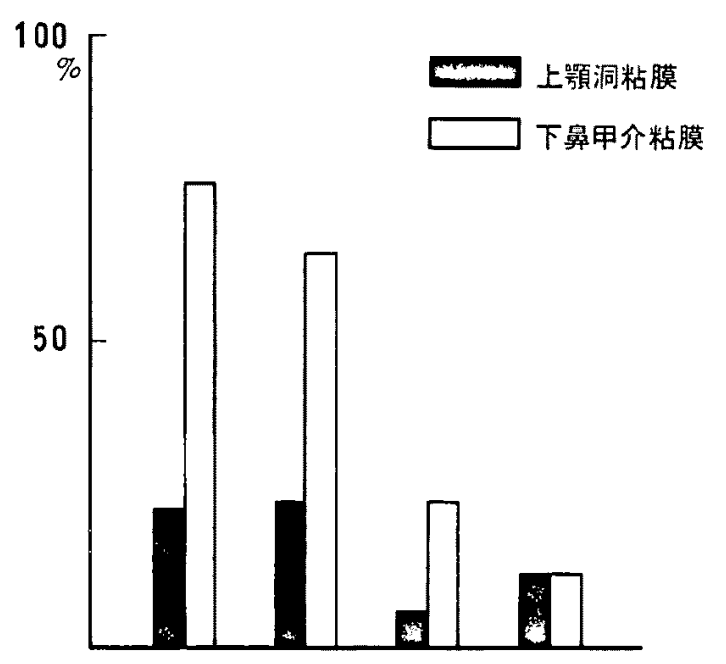

Ig $A \quad$ Ig $M \quad$ Ig $G \quad \operatorname{Ig} E$

图 5 兒疾グロブリン筹生縕胞

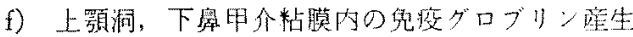

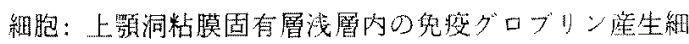
胞は，IgA では 41\%，IgM では 35\%の症例に覩察さ れ，IgG，IgEはそれそれれ $12 \% ， 18 \%$ の症例に諰めら

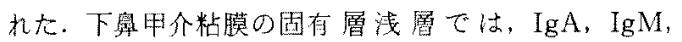
$\operatorname{IgG}, \operatorname{IgE}$ のそれぞれ $12 \% ， 18 \% ， 24 \% ， 6 \%$ の少数の

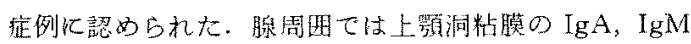

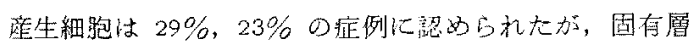

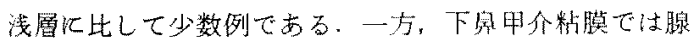

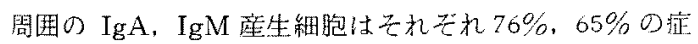
例に認められた. 一方, $\operatorname{IgG}, \operatorname{IgE}$ 产生細胞は少数例㓋 察されたにすぎなか力た（第５図）。

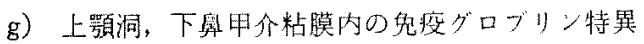

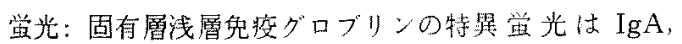

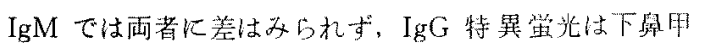
介粘膜では高度の症例が多い傾问がみられた。

\section{考算}

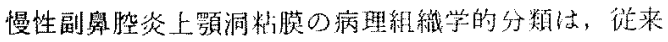

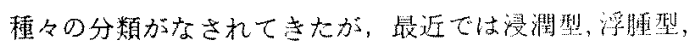

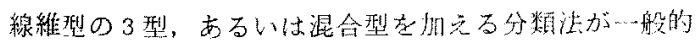

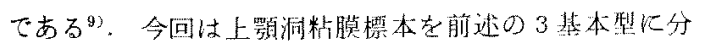

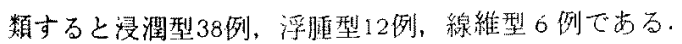

浸潤型をその細胞浸潤の程度加ら分類すると, 高度15例，

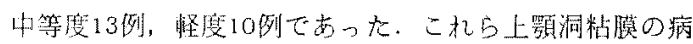

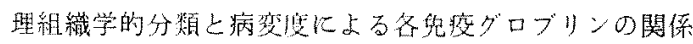
をみる上，浸潤型ではIgA 座生細胞が固有層浅層，腺周

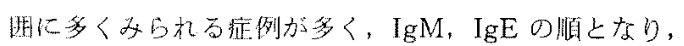

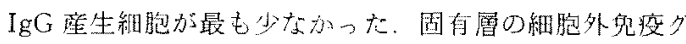
ロブリンではIgGが最も尚庭に認められ，IgA， IgMの

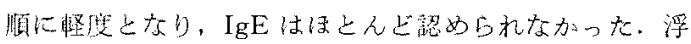

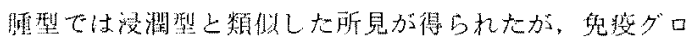
ブリン産全細胞，細胞外の局在性共に浸潤型に比して軽

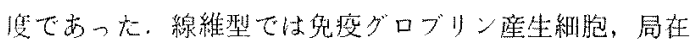
性急疫グロブリン其にはとんど誌められなかった。

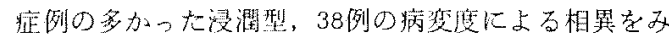

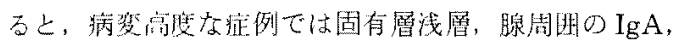

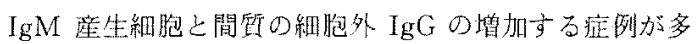

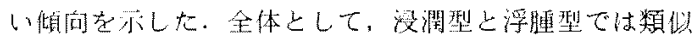

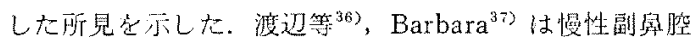

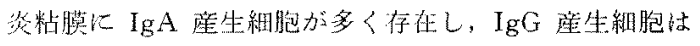

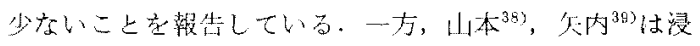
潤型ては IgG 産生組胞, 閏留細胞外の IgG が多く,

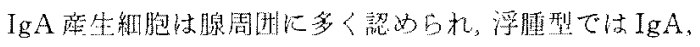

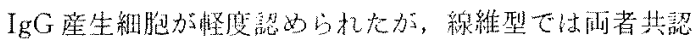
わ口机ない上赭告している。 


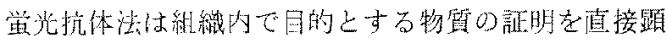
微鏡下に特異的に示してくれる点ですぐれた方法であ る、また，筫光色菜を代无ることによって（double staining)，1 組織内で 2 種類の異った物質の鑑別寻可能

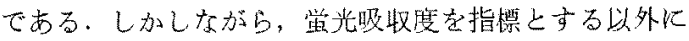

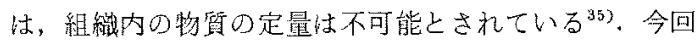
の著者の研㠰ては，同一組織内での各種先度グロブリン

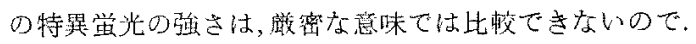
すいての標本にコントロールを置くことによって兔グ

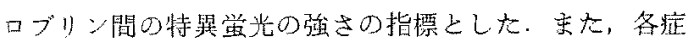

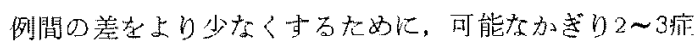
例の標本老同時に染色することに上り朲討した。

慢性副奥空㷋上顎洞粘膜中に存在する細胞内外の免疫 グロブリンは，粘膜局所爪おいてどの溙な役聙を発揮し ているのであるろか。まずIgA について考察してみる

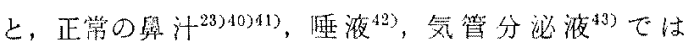
$\mathrm{IgA}$ は IgGより多く存在する。これらのIgAは正常埆

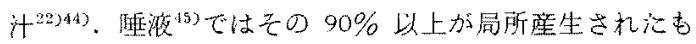
のであり，血清由来の 7s-IgA 訬铻であることも示さ れた。慢性副畄腔炎上顎洞粘膜の圆有層浅層, 腺周国に $\operatorname{IgA}$ 産生細胞方認められることは，上顎洞战膜局所で IgA妿産生されていることを示し，また，血管周国を含 わた固有層間質に細胞外IgAが認められることは，血管 よりのIgAの漏出を示すあのである.しかし、これら の IgA が 7s-IgA か 10s-IgA であるかは今回の方法

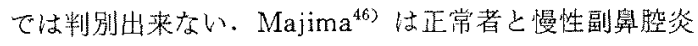

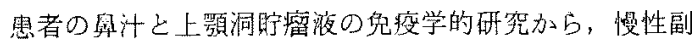

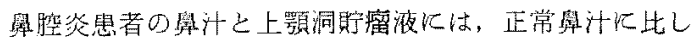
て IgA が著しく高いことをホし，この高IgAは局所産 生の10s-IgAに上り增加した症列が多いが，一部には血 清由来の $2 \mathrm{~s}-\operatorname{Ig} \mathrm{A}$ 几よる症例ああることを郝告してい

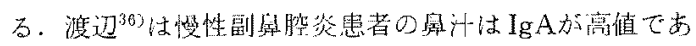
ることを示し, SC-affinity test から病䍂高度の症例で は 10s-IgA 産生細胞は 7s-IgA 㕍生細施上り少ないて

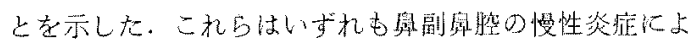
り s-IgAの器位性が低下することを示している.今回の

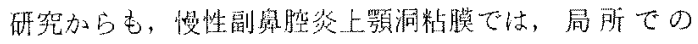

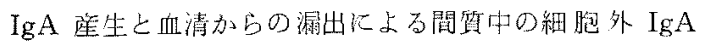
竧められた。

上枵洞粘膜の $\lg \mathrm{M}$ 産生細胞は $50 \%$ の症例の固有層

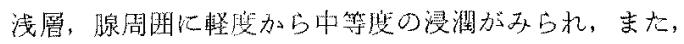
閻兵細胞外の IgMは IgAに比して兴光は整提である。

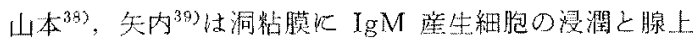

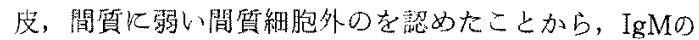
属所産生を暗示している. Eskeland ${ }^{47}$ は分泌された IgM の 60-80\% な SC 齐 conjugateしていることを示 し，Majima ${ }^{46}$ は慢性副鱟空炎患者の愿汁，上顎洞貯瘤 液に IgM が多く認められることを報告している.IgM

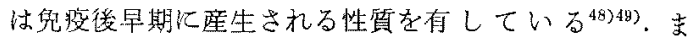

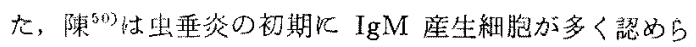
れることを示した，これらの所見加ら，IgM凊症早期 より局所であ産生され, $\operatorname{IgA}$ 亡同様 $\mathrm{s}-\mathrm{IgM}$ となり, 白

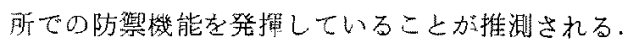

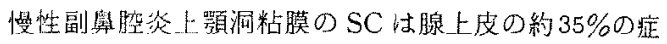
例に諗められるにすぎふかった。一方，同一症例の下舆 甲介粘膜の腺上皮では約 $82 \%$ の症例に SC が証められ た. この研究使用した FITC 抗 SC 血清性, Free $\mathrm{SC}$ と 11s-IgA K結合した SCK反応する。このため 鼣上皮細胞のSCは Free の SCをみたものか，結合し た SCをみたものかは不明でする、Majima ${ }^{46)}$ は慢性副

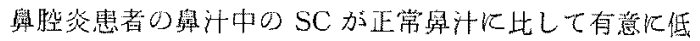

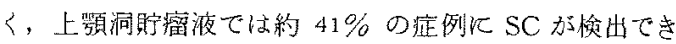

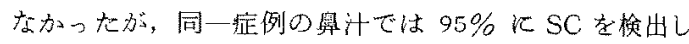

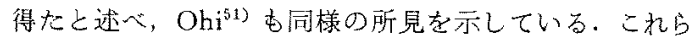
の所見加b，慢性副舆腔炎上顥洞粘膜の腺上皮では SC 産生が低下していることが明らかとなった，SC は正常 人の粘液分泌上皮上外分泌液中のいたるところ哂めら $れ^{13216)}$ ，また， SC 欠提者はすべての外分泌中心 SC 加

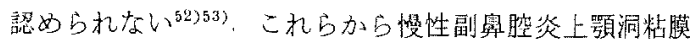

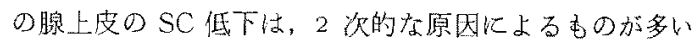
と考えられる，その原因として，1 つ权復する慢性炎 症による西接的な腺上文細胞の SC 合成阻害汃考无られ

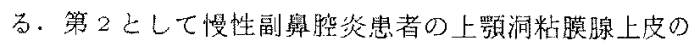

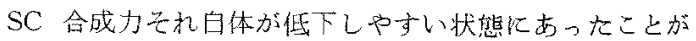

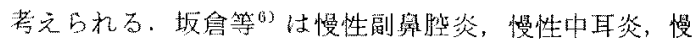
性高桃炎の息者睡液中の IgA level が涏康人にして低い

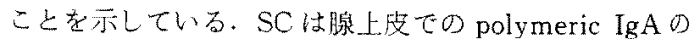
receptor となり上皮細胞に取り込み，蛋白分解酸素火

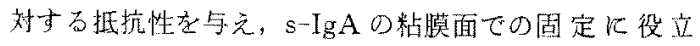

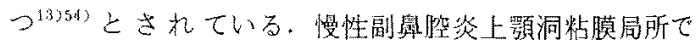
は、この样な $\mathrm{SC}$ 産坐低下による $\operatorname{IgA}, \operatorname{IgM}$ ○分泌型班 成括よび外分泌中心の榆送の低下に上る局所でのs-IgA， S-IgMの低下が执こっていることは明らかであり，この 結果己して，慢性副奥腔炎上歌洞粘膜では，萻しい同所

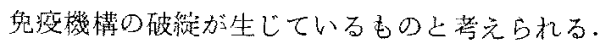

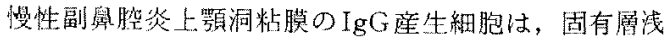


呞の約 $30 \%$ 症例に楒められたが，その部にみられた組

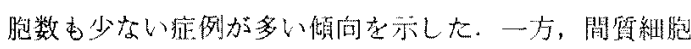

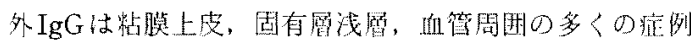

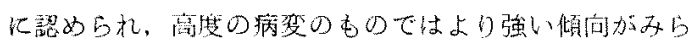
れた。これは上頡洞粘膜のIgGが血清由来であることを

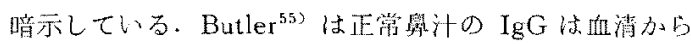

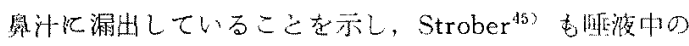

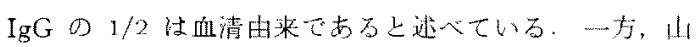

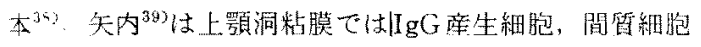
外 IgG 共に多く認めたとしている.上氮道感深後の能

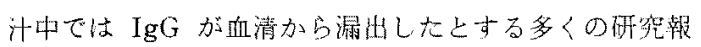

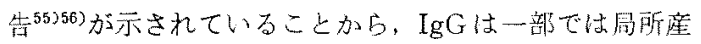
生も諗められるが，古の多くは血清由来のもの上桨古ら れ, 一度組織中に蓄椯されてから, 分泌液中に放出され るものと和むわ机る。.IgG抗体は補体柔学活性化するこ とが知られて扣り，上頡洞粘臊で抗体過剩の状態上なり， 局所でのArthus type 反度增加さ世ていることが睛示

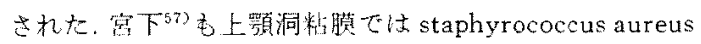

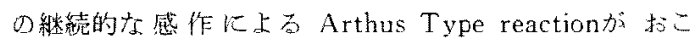

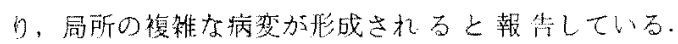

Brandtzaeg $^{19)}$ は IgGによる呞所の反心が炎祀の永続化

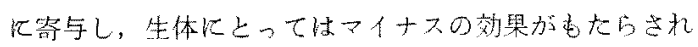

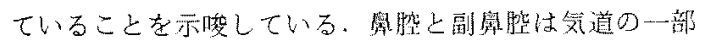

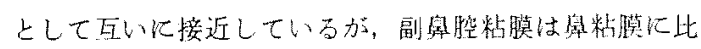

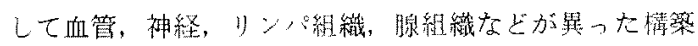
を示している ${ }^{935)}$. Brandtzaeg ${ }^{597}$ は正常奥䉼渎では IgA

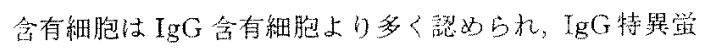

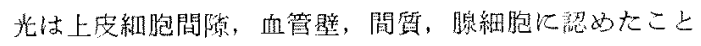

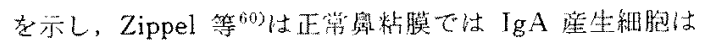

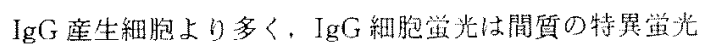

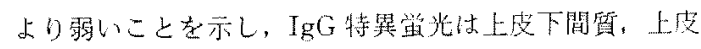

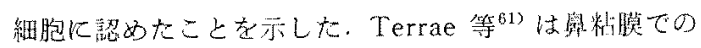

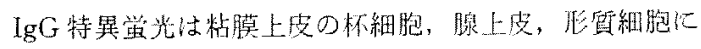

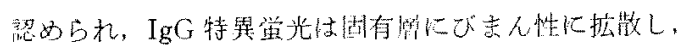

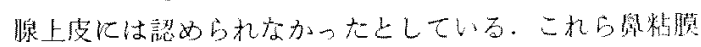

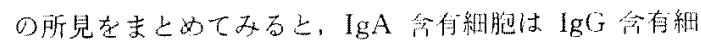

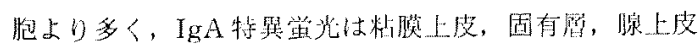

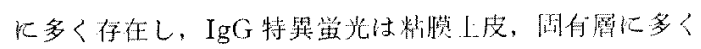
㤎められると示した報告が多い。

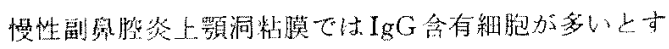

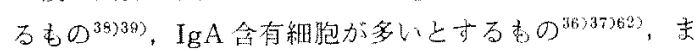

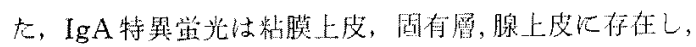

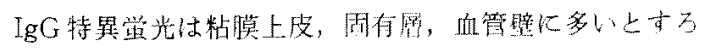

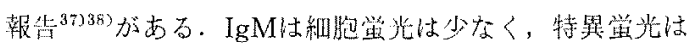

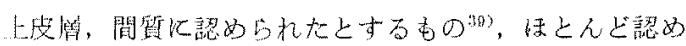
られないとするもの枋があ。 IgE について Barbra，

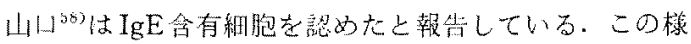

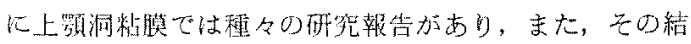

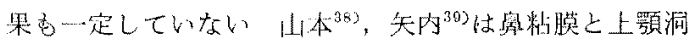

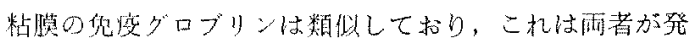
生学的国一であるとから然であるとしている。

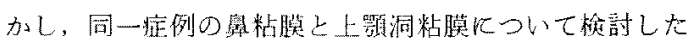

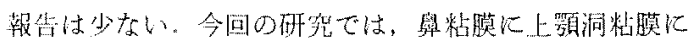

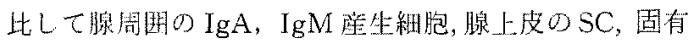

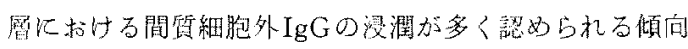

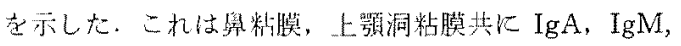

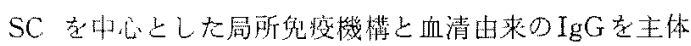

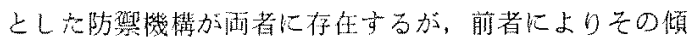

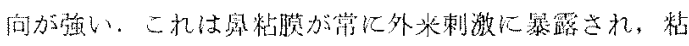
膜上坟表面の防丵のため，分记型兔疫グロブリンの分论 克進状態，血清型 IgGO漏出九淮状態になっているもの

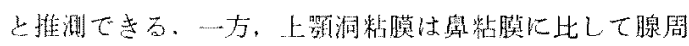

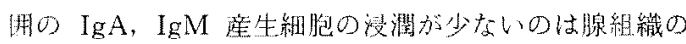

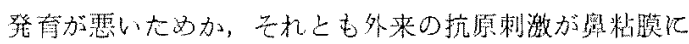
此して少小いたるか，在机と屯炎症に上る粗膜上皮之の

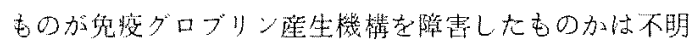

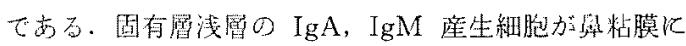

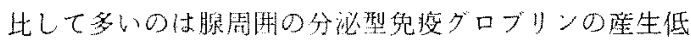

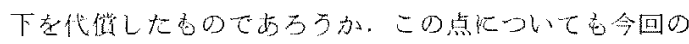

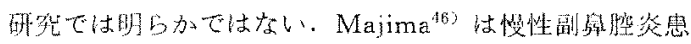

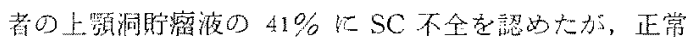
應汁では 95\%に KCを检出できたことから，岛粘膜と

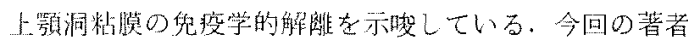

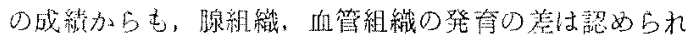

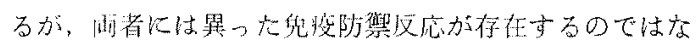
いかと执毛加た。

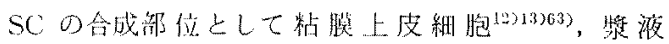
腺

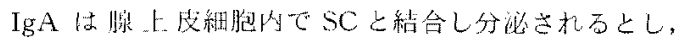

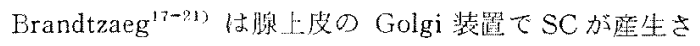

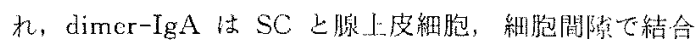

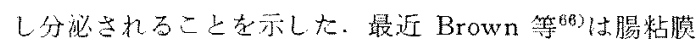

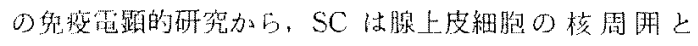
rough endoplasmic reticulum て应生され, 緗泡膜の外

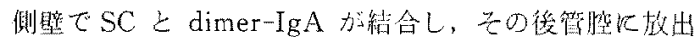

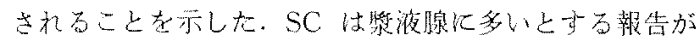




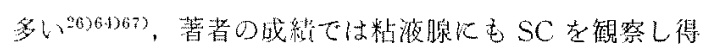

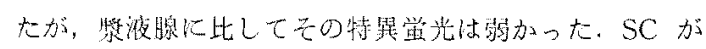

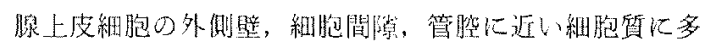

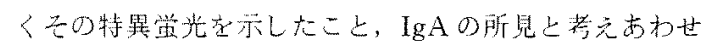

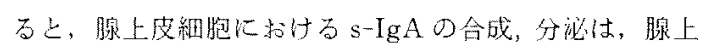

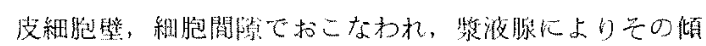

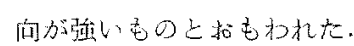

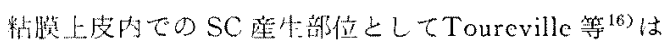
上皮の标細胞に存在するとしているが，Mogit? は数膜

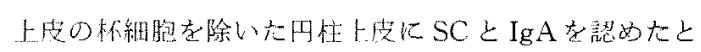
している。著者も少数の症例にSC上 IgAの特異举光が

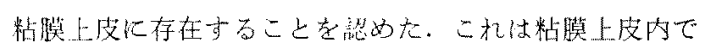
s-IgA が合成されていることを示したものであるうか，

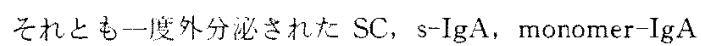
が粘蒠上皮に再吸収さ机たすのであるのかは不明であ 亏.

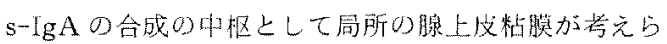
れるが，侢清中には10-15\%の dimer-IgA が証明され $ठ^{59}$. Waldman ${ }^{653}$ は正管人血清中の $\operatorname{IgA} の 1 \%$ は

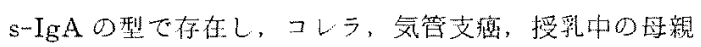
では 6\%に堌加しているとし，血清中のs-IgAは局所産 生されたものが血中に逆流し移行したものであるとし， 加納 ${ }^{593}$, Heremans ${ }^{693}$ も血中 dimer- $\operatorname{IgA}$ は, 局所で SC と結合せず血中に入ったものであるとし，s-IgAの中枢

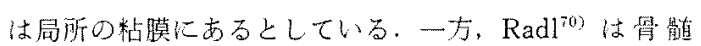
中に dimer-IgA を証明し得九とし, Polymeric-IgAの originとして骨䯠屯考无られると報告している。

$\mathrm{SC} と \operatorname{IgA} \circlearrowleft$ 結合の急䉝として， IgA が腺上皮細肜に 入り, active, selective k管腔に出るためにIgA と SC

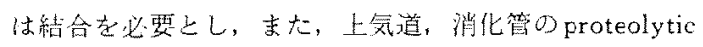

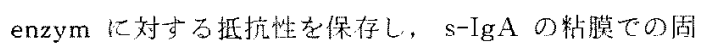

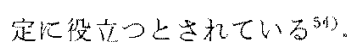

Brandtzaeg ${ }^{19}$ はこの s-IgA Kよる局所疫を first line defense $と$ 呼び, 粘漼覤内の抗原の Trapping, allergen $\sigma$ blocking, virus neutralization, Bacterial

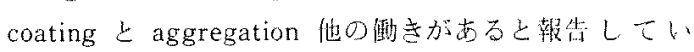
子。

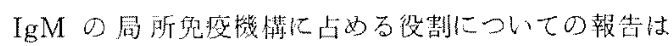

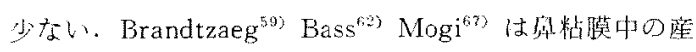

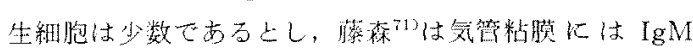

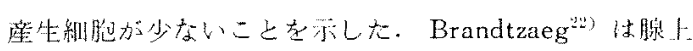
皮のIgM特琵学光上 IgA 特異兴光が同部位であること

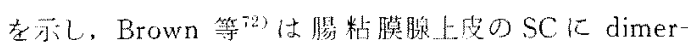

$\operatorname{IgA}$ 上IgM が同部位に結合するこ上を至した. Eskeland $^{47}$ 活分必された IgM は SC t 60-70\% conjugate していたこと加ら，IgM は $\mathrm{s}-\operatorname{IgA}$ と同様，眿上皮て s-IgMとなり外分必されることを西した。著者古腺周囲 KIgM産生縕胞が多く称められたこと，腺上皮に特異学

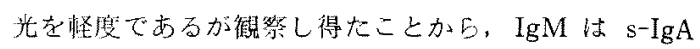
上同様儿局所産生され外分泌されているものと考克る。

$\operatorname{IgM} の$ 機能上しては $\mathrm{s}-\operatorname{IgA}$ と同様の听見が得られた

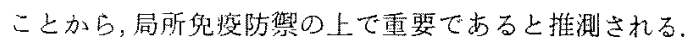

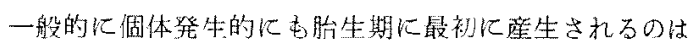

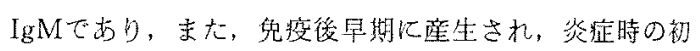

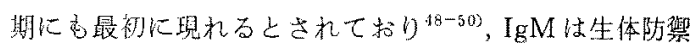

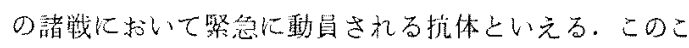

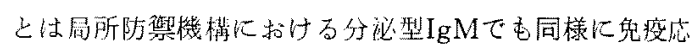
答で最初に現われるものであるうかとの疑問が生ずる。

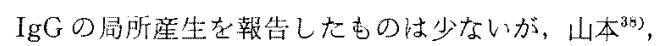

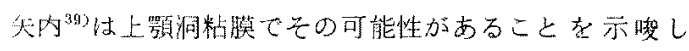

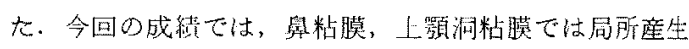
の IgG は少なく，血清からの漏出が箸明であった。池

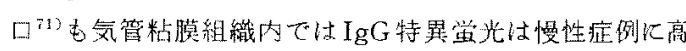
度にみられることを示した。.Brandtzaeg ${ }^{19)}$ は IgG 産生 細胞は终症が慢性北し，長期飞なると高所飞多く濯出し てくることを示し，これをIgAの first line defense 刘して second line defense $と$ 呼び, protectiveな莇㐊

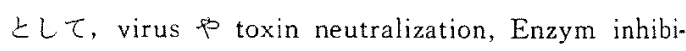
tion, allergen blocking, Bacteriolysis, opsonization tc 上げている。しかし SC 産生腺細胞にIgGを检出できな にことは，外分泌液中への IgGの輸送は $\operatorname{IgAp~} \operatorname{IgM} と$ は異った mechanismで括こっているもの上打もわれる。

\section{結} 語

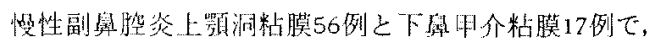

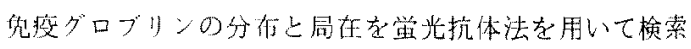
して次の綘果を得大。

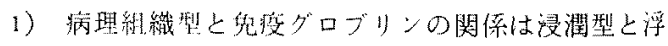

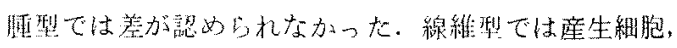

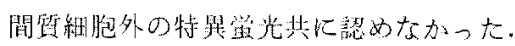

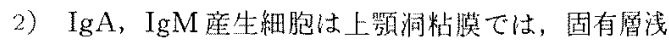

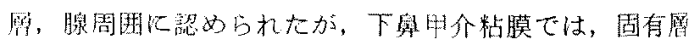

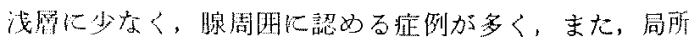

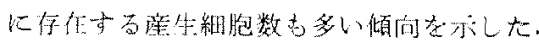

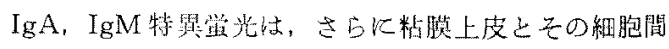

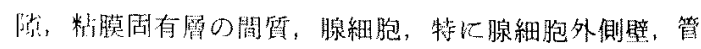




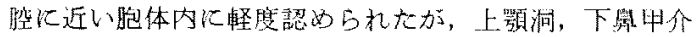
粘膜との間には差は諗められなかった。

IgAはIgMに比して麾生細胞の数, 間質稩胞外の特 基学北共に高度であった。

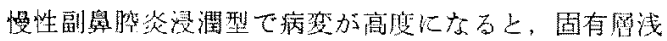
腺周用の $\operatorname{IgA}, \operatorname{IgM}$ 産生維胞数が增加する傾向を示

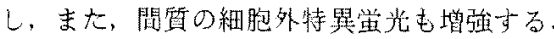

6) SC は上顎洞粘膜の $30 \%$ の症例飞琹め大にすき ない，一方，同一症例の下奥甲介粘罩では $82 \%$ 症例

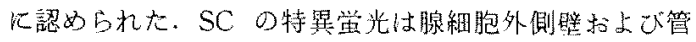

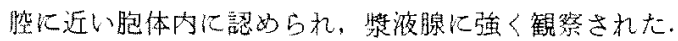

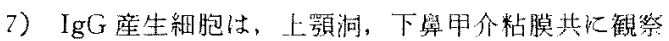
された柾例は少なか力た。

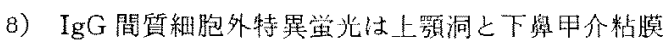

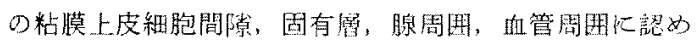
られ，上嘪洞粘膛では病変の高叟な症例はIgA，IgMに 比して，乙の特鼠蛍光も强い症例が多かった。

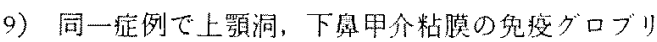
ン産生細胞は，算一クローン性ではなく，また，特に 免疫グロリブンの優位性毛哂めなか力た。

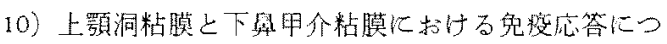
いては，前者は固有㾖上眿上皮を中心として扣り，後者 は腺上皮阮ての吣上なっていると拈も秃，雨者には

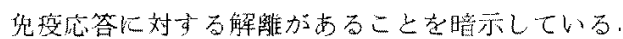

\section{参考文献}

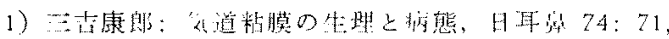
1971

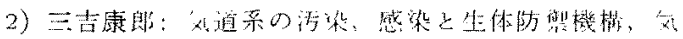

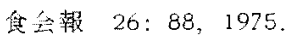

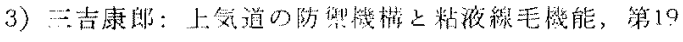

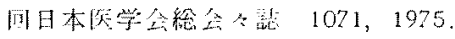

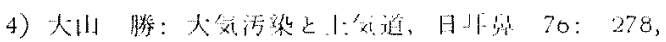
1973.

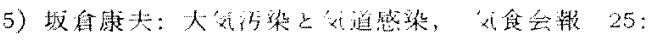
259, 1974.

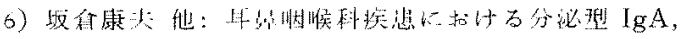
日月多 $78: 14,1975$.

7) Sakakura $Y$ et al: Mucociliary functions during experimentally induced rhinovirus infection in man. Ann Otol 82: 203, 1973.

8) Wakabayashi $M$ : Direct immunofluorescent studies on influenza virus infection in the re- spiratory tract of normal and immunosuppressed mice. The Mie Medical Journal 23: 53, 1973.

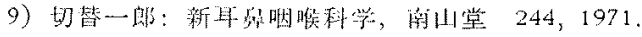

10) Besredka $A$ : De la vaccination contre les etats typhides par la voie buccale. Ann Inst Pasteur 33: $882,1919$.

11) Tomasi $T$ B Jr and Zigelbaum $S$ : The selective occurrence of rA globulins in certain body fluids' J Clin Invest 42: 1552, 1963.

12) Tomasi $T B$ et al: Characteristics of an !mmune system common to certain external secretions. J Exp Med 121: 101, 1965.

13) Tomasi $T B J r$ and Binenstock J: Secretory immunoglobullins. Adovanc Immunol 9: 2, 1968.

14) Tomast $T$ B Jr and Earle Decoteau: Mucosal antibodies in respiratory and gastrointestinal disease. Adv Intern Med 16: 401, 1979

15) Tomasi $T B$ Jr: Secretory immunoglobulins. New England J Med 287: 500, 1972.

16) Toureville $D R$ et al: The human secretory immunoglobulin system: Immunohistological locarization of a secretory "piece" and lactoferin in normal human tissuees. J Exp Med 129: 441,1969

17) Brandtzaeg $P$, Fjellanger $I$ and Gjeruldsen $S T$ : Localization of immunoglobulins in human nasal mucosa. Immunochem 4: 57, 1963.

18) Hanson L A and Brandizaeg P: Secretory antibody system, in (Immunologic disorders in infants and children) (E. R. Stiehn \& V. A. Fulginiti), p. 107, W. B. Saunders, Philadelphia, 1973.

19) Brandtzaeg L: Structure, synthesis, and external transfer of mucosal immunoglobulihs. Ann Immunol 124: 417, 1975.

20) Brandtaaeg $P$ : Mucosal and grandular distribution of immunoglobulin components. Immunohistochemistry with a cold ethanol-fixation technique. Immunology 26: 1101, 1974.

21) Brandtaaeg $P$ : Mucosal and glandular distribution of immunoglobulin components: Differential localization of free and bound $\mathrm{sc}$ in secretory epithelial cells. J Immunol 112: 1553, 1974. 
22) Brandtzaeg P: Human secretory immunoglobulin $\mathrm{M}$. An Immunochemical and Immunohistochemical study. Immunology 29: 559, 1975.

23) Donovan $R$, Johansson $S G O$, Bennich $H$ and Stoothill I F: Immunoglobulins in nasal polyp Aluid. Int Arch Allergy 37: 154, 1970.

24) Tada $T$, Ishizaka $K$ and Henney C S: Gamma -E forming cells in the human and monkey lymphoid tissues (abstract). Fed Proc 2840: $766,1969$.

25) Ishizaka $K$ and Newcomb $R W$ : Presence of $E$ in nasal washings and sputum from asthmatic patients. J Allergy 46: 197, 1970.

26) Adinolfi M, Glynn $A A$, Lindsay $M$ and Milne C M: Serological properties of IgA antibodies to Escherichia coli present in human colostrum. Immunology 10: 517, 1966.

27) Williams $R C$ and Gibbons $R J$ : Inhibition of bacterial adherence by secretory immunoglobulin A: A mechanism of antigen disposal. Science 177: 697, 1972 .

28) Burdon $D W$ : The bactericidal action of Immunoglobulin A. J Med Microbiol 6: 131, 1973.

29) Waldman $R H$ and Ganguly $R$ : Immunity of infections on secretory surface. J Infect Dis 130: 419, 1974.

30) Ammann $A J$, Cain W A, Ishizaka $K$, Hong $R$ and Good $R$ A: Immunoglobulin $E$ deficiency in ataxia-telangiectasia. New Eng J Med 281: $469,1969$.

31) Ammann $A$ I and Hong $R$ : Selective IgA deficiency. Medicine 50: 223, 1971.

32) Polmar SH, Waldman TA, Balestra ST, Jost $M C$ and Terry WD; Immunoglobulin $E$ in immunologic deficiency diseases. J Clin Invest $51: 326,1922$.

33) Berdal $P$ et al: Immunodeficiency syndromes with otorhinolaryngological manifestations. Acta Otolaryngol 82: $185,1976$.

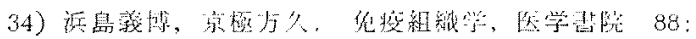
1975.

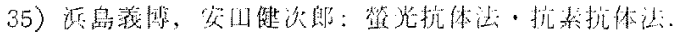
医学曺院 3:1974.

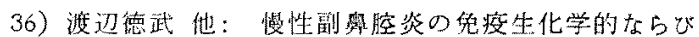

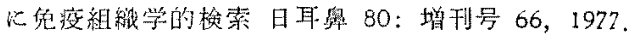

37) Barbara Zeromska: Immunological aspects of maxillary sinuitis. J Max -Fac Surg 2: 242, 1974 ,

38）山本一男：慢性上䫑洞炎洞粘膜に蛙ける独疫ヷロブ

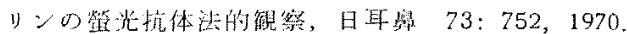

39) 矢内宏昌：慢性上顎洞炎D免疫学的矿究，耳展 20 : 175,1977

40) Lorin $M L$, Gaerland $P F$ and Mandel $I D$ : Quantitative composition of nasal secretions in normal subjects. J Lab Clin Med 80: 275, 1972.

41) Rossen R D, Shade A L, Butler $W T$ and Kasel $J L$ : The proteins in nasal secretion: A longitudinal study of $\gamma \mathrm{A}$-globulin, $\gamma \mathrm{G}$-globulin, alubumin, siderophilin, and total protein concentration in nasal washings from adult male volunteers. J Clin Invest 45: 768, 1966.

42) Brandtzaeg $P$, Fjellanger $I$ and Gjeruldsen $S T$ : Human secretory immunoglobulins 1. Salivary secretions from individuals with normal or low levels of serum immunoglobulins. J Haemat Suppl 12: 1, 1970.

43) Deuschl $H$ and Johansson $G O$ : Immunoglobulins in tracheobronchial secretion with special reference to IgE. Clin Exp Immunol 16: 401, 1974.

14) Butler W $T$, RossenR $D$ and Waldmann $T A$ :

The mechanism of appearance of Immunoglobulin $A$ in nasal secretion in man. J Clin Invest 46: 1883,1962

45) Strober $W$, Blaese $R M$ and Waldman $T A$ : The origin of $\operatorname{IgA}$. J Lab Clin Med 75: 856, 1970

46) Majima $Y$ : Nasal Immunoglobulin in health and chronic sinusitis. Mie Med J 27: 37, 1977.

47) Eskerand $T$ et al: Does I chain midiate the combination of $19 \mathrm{~s} \operatorname{IgM}$ and dimeric $\operatorname{IgA}$ with the secretory component rather than being neces. sary for their polymerization. Immunochem 11: $161,1974$.

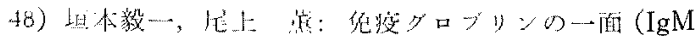

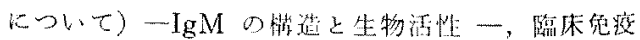


5: $1221,1973$.

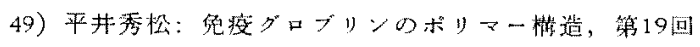
日本医学全総全全誌 $627,1925$.

50) 陳 世毣: Cellusar sites of immunoglobulins (绝 疫グロブリン含有勫胞の分布について）京都大学学 位諭文焦 $333,1973$.

51) Ohi $M$ : Immunochemistry of maxillary sinus secretion from patient with chronic sinusitis, a longitudinal study. (in preparation)

52) Strober $W$, Krakauer $R$, Klaevema $H L$, Reynolds $H Y$ and Nelson $D L$ : Secretory component deficiency: A disorder of the IgA immune system, New Engl J Med 294: 351, 1976.

53) 加秋证: 等: Secretory component deficiency: A new disease of syndorom, H佔会誌 40:740, 1977.

54) 加納 正: IgA系, 感染-炎轿-免疫 8：135, 1978 .

55) Butler WT, Waldman $T A$, Rossen $R$, Douglas $R G$ and Couch $R B$ : Changes in $\operatorname{Ig} A$ and IgG concentrations in nasal secretions prior to the appearence of antibody during viral respiratory infection in man. J immunol 105: 584, 1970.

56) Mygind $N$, Weeks $B$ and Ullman $S$ : Quantitative determination of immunoglobulins in nasal secretion. Int Archs Allergy appl Immun 49: $99,1975$.

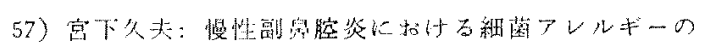

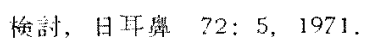

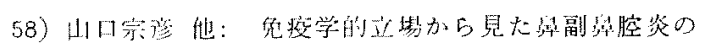

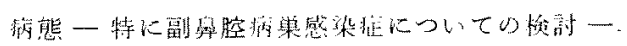
牙琁 43: 341, 1971 .

59) Brandtzaeg $P$ et al: Localization of Immunoglobulins in human nasal mucosa. Immunochem 4: $57,1967$.

60) Zippel $R$, Werne $E$ and Meyer $P$ : Zur immunhistochemischen Lokalisation der Immunglobuline $A$ und $G$ in der Nasenschleimhant des Menschen. Laryng Rhinol 55: 31, 1976.

61) Terrahe $K$ and Radu $H J$ : Die Immunglobuline in der minschlichen Nasenschleimhaut. Laryng Rhinol 53: 66, 1974.

62) Bass $R M$ te al: Immunofluorescent localization of immunoglobulins in nasal polyp. Arch Oto- laryngol 99: 446, 1974.

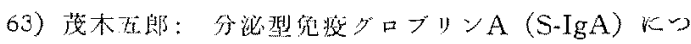

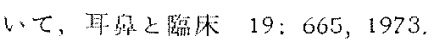

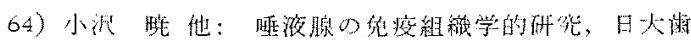
婄 $49: 782,1975$.

65) Rosen $R D$ et al: Localization of $11 \mathrm{~s}$ external secretory $\operatorname{Ig} A$ by immunofluorescence in tissues lining the oral and respiratory passages in man. J Immunol 100: 707, 1968.

66) Brown WR, Isobe $Y$ and Nakane P: Studies on translocation of immunoglobulins across intestimal epithelium. II. Immunoelectroscopic localization of Immunoglobulins and secretory component in human intestinal mucosa. Gastoroenterology $71: 985,1976$.

b7) Mogi $G$ : Secretory immunoglobulin a in oral and respiratory passages in man. Ann Otol Rhino Laryngol Suppl 20, 84: 3, 1975.

68) Waldman $R H$ : Secretory IgA in human serum. J Immunol 105: 43, 1970.

69) Heremans $J F$ : The IgA system in connection with local and systemic immunity. Adv Exp Med Biol 45: 3, 1974.

70) Radl $J$ et al: The origin of monomiric and polymiric forms of $\operatorname{IgA}$ in man. Adv Exp Med Biol 45: 57, 1974 .

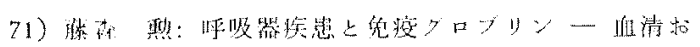

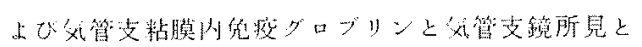

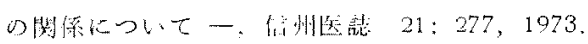

72) Brown WR et al: Studies on translocation of immunoglobulin across intestinal epithelium. IV. Evidence for binding of $\operatorname{IgA}$ and $\operatorname{IgM}$ to secretory component in intestinal epithelium, Gastroenterology $73: 1333,1977$.

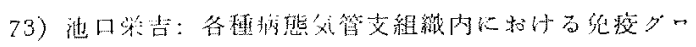

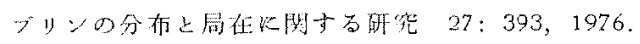

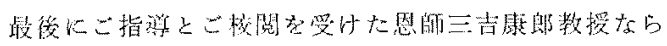

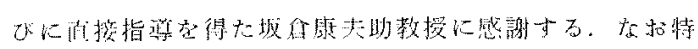

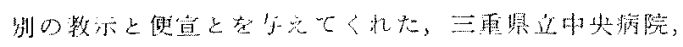

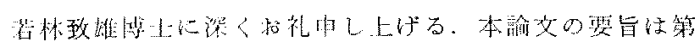

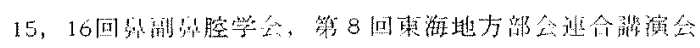
モ曰游した。 
(原稿受付 略和 $55 ， 2 、 14$ 日)

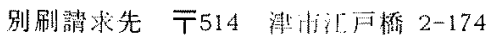

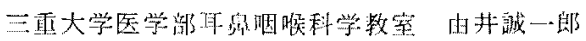

\section{付图説 明}

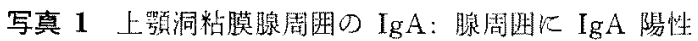

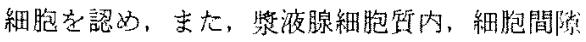
に弱い鉴光を誌める。( $(\times 400)$

写真 2 上呞洞粘膜固有層浅層の $\mathrm{IgG}$ ：固有啳飞 $\mathrm{IgG}$

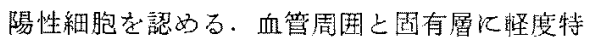
異蛍光を認める. $(\times 100)$

写真 3 上顎洞粘膜上皮の $\operatorname{IgG}: \operatorname{IgG}$ 特罢学光は备部位

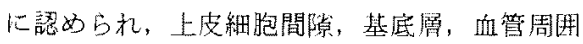
儿强く認められる。(×200)

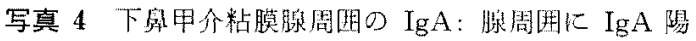
性細胞を認め, 装液腺粘液腺の組胞閒㩐に弱い

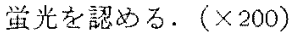

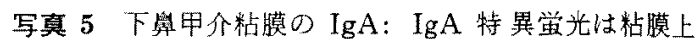

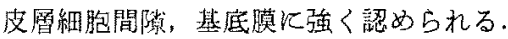
$(\times 100)$

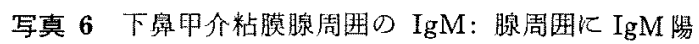
性細胞方㑇められる。(

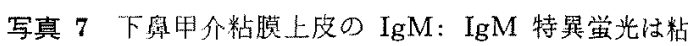

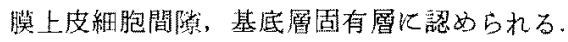
$(\times 200)$

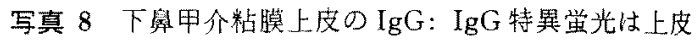
細胞間隙, 固有層, 腺周国注認められるが腺上 皮には認めら机ない。( $\times 100)$

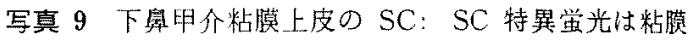
上皮尿江認められ，腺上皮のそれは弱い。 ( $\times 100)$

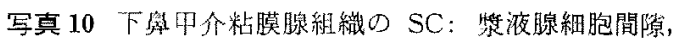

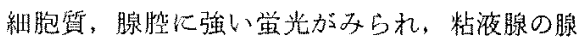

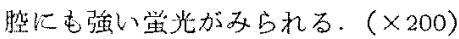

